\title{
Time Course from First Symptom to the Treatment of Lung Cancer in the Eastern Black Sea Region of Turkey
}

\author{
Tevfik Özlüa Yılmaz Bülbüla Funda Öztuna ${ }^{a}$ Gamze Çan ${ }^{b}$ \\ Departments of a Chest Diseases and bPublic Health, Karadeniz Technical University Medical School, \\ Trabzon, Turkey
}

\section{Key Words}

Delay in diagnosis - Lung cancer - Delay in treatment

\begin{abstract}
Objectives: To determine the delay between the onset and the diagnosis and treatment of patients with lung cancer in two cancer centres in the Eastern Black Sea Region of Turkey. Subjects and Methods: The records of 226 patients ( 217 males, 9 females) were evaluated retrospectively for the dates noted for the onset of symptoms, first presentation to a physician, histopathological diagnosis and start of treatment. The median time intervals from the appearance of the first symptom to definitive diagnosis and treatment were calculated. Results: The patients presented to their physicians 30 (range 2-365) days after their complaints began. The time that elapsed between admission and histopathological diagnosis and between the diagnosis and initiation of therapy were 8 (range 1-210) and 17.5 days (range 0-206), respectively. The median time span from presentation to treatment was 30 days (range 1-253). There were no significant time interval differences between onset of symptoms and first presentation and the subsequent diagnostic and therapeutic processes for histopathology, stage of the
\end{abstract}

\begin{tabular}{ll}
\hline KARGER & ( ) 2004 S. Karger AG, Basel \\
1011-7571/04/0134-0211\$21.00/0 \\
$\begin{array}{l}\text { Fax + 4161306 12 34 } \\
\text { E-Mail karger@karger.ch } \\
\text { www.karger.com }\end{array}$ & $\begin{array}{l}\text { Accessible online at: } \\
\text { www.karger.com/mpp }\end{array}$
\end{tabular}

tumour and treatment procedures $(p>0.05)$. Conclusion: Reasons for the delayed treatment of lung cancer patients were late presentation to the physician and the long time interval between tissue diagnosis and treatment. This delay was mostly associated with a large number of patients and delayed appointments for imaging procedures - the result of organisational problems within the health services of Turkey.

Copyright $\odot 2004$ S. Karger AG, Basel

\section{Introduction}

Surgery still remains the most effective method for the treatment of lung cancer. However, most people with lung cancer present to their physicians when the cancer has reached an advanced stage and it has become too late for surgical treatment. Further delays may take place at diagnostic stages or when treatment is being arranged. This time lag before the start of treatment may negatively affect the patient's chances of survival and/or quality of life.

The time interval between the onset of symptoms and the start of treatment depends on various factors such as patient behaviour, clinical course of the illness and the 
Table 1. Patient profile, smoking status and tumour type

\begin{tabular}{|c|c|c|}
\hline & $\mathrm{n}$ & $\%$ \\
\hline \multicolumn{3}{|l|}{ Sex } \\
\hline Male & 217 & 96 \\
\hline Female & 9 & 4 \\
\hline Mean age, years $\pm \mathrm{SD}$ & $61.3 \pm 10.3$ & \\
\hline \multicolumn{3}{|l|}{ Smoking status (216 subjects) } \\
\hline$\geq 20$ cigarettes/day & 180 & 83.3 \\
\hline $1-20$ cigarettes/day & 14 & 6.5 \\
\hline Other (non-smoker, passive smoker, etc.) & 22 & 10.2 \\
\hline Age at start of smoking, years \pm SD & $21.4 \pm 8.2$ & \\
\hline Time smoked, years \pm SD & $35.8 \pm 12.6$ & \\
\hline \multicolumn{3}{|l|}{ Histopathological diagnoses (218 subjects) } \\
\hline Squamous cell carcinoma & 146 & 67 \\
\hline Small cell carcinoma & 34 & 15.6 \\
\hline Adenocarcinoma & 22 & 10.1 \\
\hline Bronchioloalveolar cell carcinoma & 4 & 11.8 \\
\hline Other lung carcinomas & 12 & 5.5 \\
\hline \multicolumn{3}{|l|}{ Tumour stages } \\
\hline \multicolumn{3}{|l|}{ Non-small cell } \\
\hline Stage I/II & 27 & 11.9 \\
\hline Stage IIIa & 43 & 19.0 \\
\hline Stage IIIb & 78 & 34.5 \\
\hline Stage IV & 44 & 19.5 \\
\hline \multicolumn{3}{|l|}{ Small cell } \\
\hline Limited disease & 9 & 4.0 \\
\hline Extensive disease & 25 & 11.1 \\
\hline
\end{tabular}

quality of the health services [1,2]. Although several studies assessing delays in the diagnosis and treatment of lung cancer have been published in some countries [3-10], we have not encountered a similar report in Turkey as yet. Therefore this study was undertaken to assess the delay from the onset of symptoms to the first presentation to a physician and the subsequent diagnosis and treatment in two cancer centres in the Eastern Black Sea Region in Turkey.

\section{Subjects and Methods}

\section{Patients}

The records of 226 patients ( 217 males, 9 females) with lung cancer diagnosed between January 1992 and December 1999 at the Farabi Hospital of Karadeniz Technical University (Departments of Chest Diseases and Oncology) or the Trabzon Chest Diseases Hospital were evaluated retrospectively. All people with suspected lung cancer from 7 cities in the Eastern Black Sea Region are referred to these 2 centres because they are the only 2 hospitals in the region with facilities for cancer diagnosis and treatment. The dates of onset of symptoms, first presentation to a physician, histopathological diagnosis and start of treatment were determined, and the time intervals
Table 2. Time intervals between onset of symptoms, definitive diagnosis and treatment of patients (in days)

\begin{tabular}{lcc}
\hline Time interval & $\begin{array}{l}\text { Median day } \\
\text { (range) }\end{array}$ & $\mathrm{n}$ \\
\hline From first symptom to presentation & $30(2-365)$ & 216 \\
From presentation to tissue diagnosis & $8(1-210)$ & 196 \\
From diagnosis to treatment & $17.5(0-206)$ & 132 \\
From presentation to first treatment & $30(1-253)$ & 127 \\
From symptoms to treatment & $71.5(3-429)$ & 126 \\
\hline
\end{tabular}

from first symptoms to admission, from admission to definitive diagnosis, and from diagnosis to start of treatment were calculated.

\section{Statistical Analysis}

The median delays in the patients with different histopathological types and stages and the median delay for different treatment procedures were compared using the Kruskal-Wallis test. The Kruskal-Wallis test was also used for the comparison of annual delays from 1992 to 1999 to detect any possible improvement in diagnostic and therapeutic process. $\chi^{2}$ test was used to assess whether the type of symptom had any effect on the delay of time to first presentation; $\chi^{2}$ test was also used to compare the time elapsed between diagnosis and treatment. $\mathrm{p}$ values $<0.05$ were considered to be significant.

\section{Results}

Detailed information on the patients, including smoking status, histopathological diagnosis, and tumour stage, is shown in table 1. Tissue diagnosis was obtained in 218 patients (96.5\%). Chemotherapy, radiotherapy and surgery alone were performed in 20.4, 27.0 and $11.5 \%$ of the patients, respectively. Adjuvant radiotherapy and combined therapy (radiotherapy plus chemotherapy) were performed in 1.8 and $1.3 \%$, respectively, and supportive therapy was performed in $14.6 \%$ of the patients. The treatment methods in $53(23.4 \%)$ patients were not recorded due to referrals or deaths.

The time intervals between the onset of symptoms, presentation at the hospital, diagnosis, and treatment are given in table 2. Patients waited 30 days (range 2-365) after onset of symptoms before seeing a doctor. The time between presentation to the pulmonologist and treatment was 30 days (range 1-253): for surgical treatment it was 35 days (range 2-123), chemotherapy 28.5 days (range 1-196) and radiotherapy 36 days (range 6-253). The delay was not statistically different between the different treatment options. Table 3 shows time intervals between admission, diagnosis and treatment. Although $70.9 \%$ of 
Table 3. Time intervals between admission, diagnosis, and treatment (in patient numbers)

\begin{tabular}{lllllcr}
\hline Time interval & \multicolumn{2}{l}{ Time elapsed } & & Total & Expected & $\mathrm{p}$ \\
\cline { 2 - 5 } & $\begin{array}{l}<3 \text { weeks } \\
(0-14 \text { days })\end{array}$ & $\begin{array}{l}3 \text { weeks } \\
(15-21 \text { days })\end{array}$ & $\begin{array}{l}\geq 3 \text { weeks } \\
(\geq 22 \text { days })\end{array}$ & & \\
\hline Between admission and tissue diagnosis & $139(70.9 \%)$ & $32(16.3 \%)$ & $25(12.8 \%)$ & 196 & 65.3 & 0.000 \\
Between diagnosis and treatment & $60(45.5 \%)$ & $15(11.3 \%)$ & $57(43.2 \%)$ & 132 & 44 \\
Between admission and first treatment & $31(24.4 \%)$ & $17(13.4 \%)$ & $79(62.2 \%)$ & 127 & 42.3 & 0.000 \\
\hline
\end{tabular}

patients were diagnosed within 2 weeks of presentation at the pulmonologist, less than half the patients started therapy within 2 weeks following the histopathological diagnosis.

The delays from the onset of symptoms till the first contact with a pulmonary physician for squamous cell carcinoma, small cell carcinoma and adenocarcinoma were the same ( 30 days, range $2-365$ days; $p>0.05$ ). A similar median delay of 30 days but different ranges were observed for the different stages of non-small cell carcinomas (2-180 days for stage I/II, 2-365 days for stages III and IV), and for the limited and extensive stages of small cell carcinoma (2-365 days) and (7-60 days), respectively. The time intervals from first contact until the diagnostic and therapeutic steps were also similar according to histopathology, stage of the tumour and treatment procedure. The time period necessary for diagnosis and treatment of lung cancer remained unchanged in each year between 1992 and 1999.

The most common symptom at presentation was cough $(62.8 \%)$, followed by dyspnea $(33.3 \%)$, sputum (24.3\%), weakness (13.7\%), weight loss (16.4\%) and haemoptysis (11.9\%). Patients with symptoms of cough, weakness or haemoptysis presented within the range of 2-365 days, those with sputum within 2-270 days and those with weight loss within 2-180 days; for these patients the median delay duration was 30 days. Although patients with dyspnea presented within the same range of 2-365 days, the median delay duration was longer (60 days).

\section{Discussion}

The rather long time between the onset of patients' complaints and presentation to the chest physician found in this study may be due to several factors, such as preexisting chronic lung disease, long-standing effects of smoking, and the severity and character of the pulmonary symptoms, as well as patients' attitudes towards cancer particularly fear and apathy. Further delays could also be due to organisational problems in the health care services, such as absence of a family physician and no regulated referral system between primary health care and secondary/tertiary health care systems in Turkey, which allows patients to see a number of different physicians prior to referral to a pulmonologist. However, since this report is a retrospective study, the exact causes of delay could not be determined. Although the range (2-365 days) of the time interval between onset of symptoms and presentation in this study is long, the median interval of 30 days is within that reported in other studies: $30-110$ days in Brazil [3,5], 166 days in Malaysia [4] and 3-4 weeks in the UK [6, 7].

The median 8-day delay in obtaining tissue diagnosis in this study is consistent with the British Thoracic Society (BTS) recommendation of 2 weeks after the first presentation [11]. Again it should be pointed out that the range of 1-210 days was quite long, however, for a majority of the patients (70.9\%) the diagnosis was made within 2 weeks. Only a minority (12.8\%) was made after 4 weeks. Our median 8-day delay is also similar to that reported from England [6, 12], but dissimilar to the 33 days [3] and 90 days [5] reported from Brazil and one other report of 28 days [8] from England.

With regard to the time interval from first presentation or diagnosis to treatment the BTS suggests a maximum of 2 weeks for palliative radiotherapy, 4 weeks for radical radiotherapy and 8 weeks for thoracotomy. In this study, the 35-day delay for surgery was within the time interval suggested by the BTS, while the delays for chemotherapy (28.5 days, range 1-196) and radiotherapy (36 days, range 6-253) were longer than that recommended by BTS. The interval between onset of symptoms and treatment was similar to other studies $[6,7,10]$. In this study, the reasons for a longer time interval between diagnosis and treatment were delays in treatment appointments and diagnostic procedures. 


\section{Conclusion}

Although some delays between admission and diagnosis were detected in a small proportion of lung cancer patients, the main delays were observed between onset of first symptoms and presentation to a physician, and between tissue diagnosis and treatment. While the late presentation to a physician was most probably related to patient behaviour and the nature of the illness, the delay between tissue diagnosis and treatment was mostly associated with large patient numbers.

\section{References}

1 Kerdpon D, Sriplung H: Factors related to delay in diagnosis of oral squamous cell carcinoma in southern Thailand. Oral Oncol 2001; 37:127-131.

2 Pereira JR, Ikari FK, Minamoto H, Cassioli JC: Delay factors in the diagnosis of lung cancer: A public health problem (in Portuguese). Rev Paul Med 1991;109:109-112.

3 Silva PP, Pereira JR, Ikari FK, Minamoto H: Lung cancer and the delay in the diagnosis: Analysis of 300 cases (in Portuguese). Rev Assoc Med Bras 1992;38:145-149.

4 Lim KH, Liam CK, Wong CMM: Delay in the presentation of lung cancer in Malaysia. Eur Respir J 2000;16(suppl 31):S226.

5 Knorst MM, Fagundes LP, Dienstmann R, Lisboa TC: Lung cancer: Delays in diagnosis and surgical treatment. Eur Respir J 2000;16(suppl 31):S226.
6 Dische S, Gibson D, Parmar M, Saunders MI: Time course from first symptom to treatment in patients with non-small cell lung cancer referred for radiotherapy: A report by the CHART Steering Committee. Thorax 1996;51: 1262-1265.

7 Billing JS, Wells FC: Delays in the diagnosis and surgical treatment of lung cancer. Thorax 1996;51:903-906.

8 Deegan PC, Stevens S, Heath L, Brunskill J, Kinnear WJ, Johnston ID: Waiting times in lung cancer: What is achievable by a multidisciplinary team? Thorax 1996;51(suppl 3):S7.
9 Lopez Encuentra A, Martin de Nicolas JL, Casado Lopez M, de Miguel Poch E, Marron Fernandez C: Delays in the diagnosis and surgical treatment of bronchogenic carcinoma. Cooperative Group on Bronchogenic Carcinoma of SEPAR (GCCB-S) (in Spanish). Arch Bronconeumol 1998;34:123-126.

10 Milleron B, Mangiapan G, Terrioux PH, Rosencher L, Guigay J, Mayaud C: Delay in the diagnosis and treatment of lung cancer. Thorax 1997;52:398.

11 The Lung Cancer Working Party of the British Thoracic Society Standards of Care Committee: BTS recommendations to respiratory physicians for organizing the care of patients with lung cancer. Thorax 1998;53(suppl 53):S1-S8.

12 Murphy D: Lung cancer - timeliness of a rapid diagnostic service. Eur Respir J 2000;16(suppl 31):S226. 